\title{
DYNAMIC MODELS OF TECHNOLOGICAL CHANGES
}

\section{I.V. Kant orovich, V.I. shjanor}

Moscon

Ihe report is devoted to one of the probleme of mathematicel modelling of economy - the problen of modelling technological change.

Alongeide with multi-produ ot models such as the input-output model, the Von keumann model of expanding economy, models of linear progremeng, there are meroeconomic models of national economy on the basis of such aggregate indices as nationel inoome, aggregate domand, otc., which are widely applied for qualitative and quantitative analysis of economy.

Such modelg heve been develaped aloce the thirtieg: Feldman's Growth Model, research by the kejnes sohool, eepecially works by Harod, Domer, Samuelson, Hicks, Solow and other authore. It is well known that these modele have been given proctioal application in governeent regulation of economy, in measures for recueing origes, unemployment, though with partial success.

The eimplest one-product models of the development of econony can be used for global analysie of development of the economio systom and considaration of the effect of teohnologioal ohange on the dynomios af the econonde syster. On the basts of these models it is poselble to study the affect of technologiosl change on the most 1 mportant economic characteris ties.

Let us consider an econowtc sygtem in which a aingle produet is produced. One part af this produot is alleceted to consunption 
and the other part to acoumulation of I1xed and working stocks, wherea in this model no distinction 18 made between these two stocke.

Under the asauption of instantaneous transformation of cepltal stocks and consideration of technological change this mod el may be desoribed by the following equetion:

$$
\frac{d K(t)}{d t}=P(t)-V(t)=e^{\delta t} u[K(t), T(t)]-V[t, K(t), T(t), P(t)]
$$

where $P(t)$ 1o the net product or the national income;

$V(t)$ is the total consumption, given in unit time. Tho produotion Iunction $U[K(t), T(t)]$ charroterizes the amount of net output which can be produced by capital stook $K(t)$ per unit t1me and lebour resources $T(t)$, $\delta$ oharacteriaes the rete of nentral technological change.

Within the Iramework of this model an 1mportant parameter of the economio systen can be determined, 1.0., norm of efficiency of investment $\eta_{\ni}$. For $\eta_{\ni}$ the following expreseion is derf ved

$$
\eta_{\rightarrow}=\frac{\frac{1}{\rho(t)} \frac{d P(t)}{d t}-\frac{1}{T(t)} \frac{d T(t)}{d t}-\delta}{1-\frac{V(t)}{P(t)}-\frac{1}{T(t)} \frac{d T(t)}{d t} \frac{K(t)}{P(t)}}
$$

11. the variables in this Iormula have a proolso economic oontent. Calenlation of the norm of effiolency according to this formule without consideration of technological change gives a value of $22 \%$, and with consideration of technological change, lag, obsolescence of ot ooks this value is equal to $18 \%$.

As hee been pointed out, it is assumed in tha mod ol the hypothegla about the instantaneous transformation of stooks, $1.0 .$, the assumption that the atocks can always be trensformed from one form to another and, in particular, due to thie it is poselble to ohange from one production structure (Iabour-eapital ratio) to another one whout 20ss. More practicable is a silar model without the assumption about the instantaneous transformat on of stocks.

Lat us constder the structure of the one-product model. 
$T(t)$ - labour resources at lnstant $t$ is a fixed function. Fe Introduce $\lambda(t)$ - type (or atructure) of naw stocks oreated at instant of time $t$, whiok are characterized by the value (oxpressed in the produet) of single stooks (stocks per unit of labour). It is aseumed that the stocks created at each instant of time $t$ are oingle-t yo $(\lambda(t)$ - single-valued function of $t) \cdot \varphi(t)$ denot co the intensity of oreating stocks, $1.0 ., \varphi(t) d t$ is the number of new work positions created during the time $[t, t+d t]$, then

$\lambda(t) \varphi(t) d t \quad$ ls the rolume of newly created stooks in the seme interval. She runetion $\lambda(t)$ and $\varphi(t)$ in the model are subject to calculation.

It is asened that potential modes of production ore oharact er1aed by the production function $U(x, y)$, wioh indicates the amount of net produot created by labour $y$ men using the fixed stooks $x$ per unit time (at the initial instant). It is assumed that the funotion $U(x, y)$ is positively homogensous of the firet degree

$$
U(\lambda x, \lambda y)=\lambda U[x, y] \text { when } \lambda>0
$$

and based on optimal modes, which renders atural aseumtion about conrexty $U[x, 1]$.

Technological change is present in the mod ol by the following method. It is osumed that the amount of net product, produced per unit at the given quantity of stocks and expenditures of labour, inoreases exponentially depending on the instant of creating atocks $\tau, 1.0 .$, it oxoeeds by $e^{\delta \tau}$ times ( $\delta$ is ixxed non-negative number) the amount of products produced by the stooks, created the initial Instant, under the same conditions.

It is also assumed that in the process of development of the economy the labour resources are removed from stooks at lower structure, wht oh have be ereated formerly. Ihe labour resources, wheh heve boen Ireed from the romowad atocks, are used on stocks ereated anow, the reming stooks are not used subsequently. onder the assumption of oontinuous growth of eapital organic composition (new atocks) the pollcy of removing stooks from produetion is charccteried by the funotion $m(t)$, namely all at oeks which have been created up to a certain instant of time $m(t)$ are freed to the $1 n-$ stant of time $t$. The function $m(t)$ in the model is subject to determonation.

The investments for incressing the fixed and working atocks are specified through their intengity so that $\partial e(t) d t$ is rolume of 
investments at time interval $[t, t+d t]$. The function de $(t)$ is speciried in the model, however it can be placed in dependence on the national income at instant $t$ or other parametere of the model. The system of equations that describe the model takes the form:

$$
\begin{gathered}
\varphi(t)=\frac{d T(t)}{d t}-\varphi[m(t)] \frac{d m(t)}{d t} \\
\varphi(t) \lambda(t)=\partial e(t) \\
u[\lambda(t), 1] \varphi(t)-\frac{\partial u[\lambda(t), 1]}{\partial x} \partial e(t)-e^{\delta[m(t)-t]} \varphi(t) U[\lambda[m(t)], 1]=0
\end{gathered}
$$

The sygtem 1.s resolved for $t>t_{0} \quad\left(t_{0}\right.$ is a lixed number). The InItial conditions aro specilied as $m\left(t_{0}\right)=m_{0} \quad\left(m_{0}<t_{0}\right)$,

$$
\lambda(t)=\lambda_{0}(t), \varphi(t)=\varphi_{0}(t) \quad \text { when } \quad t \in\left[m_{0}, t_{0}\right]
$$

were $m_{0}$ is fixed number, and $\lambda_{0}(t)$ and $\varphi_{0}(t)$ are Innctions a at armining the initial diatribution (with $t \in\left[m_{0}, t_{0}\right]$ ) of otooks and lobonr.

squation (3) reflecto the labour balance. squation (4) rerlects the stooks balance. Equation (5) is a condition of difierential optimaation. Ihis oondition denotes that the inorease of net groduet at aeoh instant of time should be maximal, in othor words the functions $m(t), \lambda(t), \varphi(t)$ should be determined so that the funotion $d P(t) / d t$ is maximal each instant of time $t$. Here $P(t)$ is the amount of net product (netional income) producad at inotant $t$ per anit time. For $P(t)$ the following formula holds true:

$$
P(t)=\int_{m(t)}^{t} e^{\delta \tau} U[\lambda(\tau), 1] \varphi(\tau) d \tau
$$

For the norm of efficiency of investments the following formula has been derivod 


$$
n(t)=\frac{1}{\partial e(t)}\left\{\frac{d P(t)}{d t}-e^{\delta m(t)} U[\lambda[m(t)] 1] \frac{d T(t)}{d t}\right\}
$$

Lat us speotfy the next form of the functions included in equations $(3)-(5)$.

$$
U[x, y]=x^{\alpha} y^{1-\alpha} ; T(t)=T_{0} e^{p^{t}} ; \partial e(t)=t_{0} \quad \text { is a ixod }
$$

poeitive number. Jnder the assumption of poselbility of expansion or equation (3)-(5) into infintte serieg and confining ourgelves to linear terms of values $\delta$ and $\rho$ we have

$$
\begin{aligned}
& m(t)=\beta t\left[1+\delta \frac{1-\beta}{2 \alpha} t\right] \\
& \varphi(t)=\frac{1}{t}\left[1+\delta \frac{t+1}{2 \alpha}+\rho \frac{T_{0}(t+1)}{1-\beta}\right] \\
& \lambda(t)=\partial l_{0} t\left[1-\delta \frac{t+1}{2 \alpha}-\rho \frac{T_{0}(t+1)}{1-\beta}\right], \beta=(1-\alpha)^{1 / \alpha .}
\end{aligned}
$$

By means of this oolution it is poselble to obtain paramotric representation of the norm of efficiency by coefificient $\delta$ which characterites technological ohange and growth rate of labour resourese $\rho$ :

$$
n(t)=\alpha \partial e_{0}^{\alpha-1} t^{\alpha-1}\left[1+\frac{\delta(1+\alpha) t+(1-\alpha)}{2 \alpha}+p T_{0} \frac{t+1}{1-\beta}\right] .
$$

In conelusi on we shall note the possiblity to introduee withIn the framenork of the model the notion of variable tranaformability of stooks, that 18 incompl te transformallity, whoroby the degree of Incompleteness is characterized by variable coeficient.

Let us essume that the stooks removed from production (relative to its oost of reproduction) can be partiy realized and the obtained capital difroted into investment. Iet us denote part of the realized value by $\pi(0<\pi<1)$. The equations of the model 
will take the rollowing form:

$$
\begin{aligned}
& \varphi(t)=\frac{d T(t)}{d t}+\varphi[m(t)] \frac{d m(t)}{d t} \\
& \varphi(t) \lambda(t)=\partial e(t)+\pi \partial e[m(t)] \frac{d m(t)}{d t} \\
& U[\lambda(t), 1] \varphi(t)-\frac{\partial U[\lambda(t), 1]}{\partial x} \partial e(t)- \\
& -e^{\delta[m(t)-t]} \varphi(t) U[\lambda(m(t)), 1]+\pi \frac{\partial U[\lambda(t), 1]}{\partial t} \partial \varepsilon[m(t)] \frac{d m(t)}{d t}=0
\end{aligned}
$$

The formule Ior the norm of efflotency or investments 111 be changed accordingly. Under the assumption of a small value of coefficient $\pi$ we obtain for $n(t)$ the following formula

$$
n(t)=n_{0}(t)\left[1+\pi \frac{\partial[[m(t)]}{\partial e(t)} \frac{d^{2} T(t)}{d t^{2}}\right]
$$

\section{References}

1. L. V. Kentorovich, sconomic Calculation of Best utilization of Resovrces 4. UsS it kad. Nank Publishtng Houee (1959).

2. I. V. Kanterovich and h. I. Meinstein, on the calculation of the Efficienoy Norm on the Basts of One-iroduct Model of Economic Development, skonomika 1 Mat. Metody 3 (1967), 1seue 5.

3. I. V. Kantorovich and V.I. Ghjenov, A one-Product byname mod ol of Bconomi Cs, Takfng lcoount of the change in structure of stooks with Industrial Progress. Doki. Nkad. Wauk USSR, 211 (1973), No.6.

4. L.V. Kantorovich, Beonomic Problems of Technological change, Bkonomika 1 Mat. Metody, 10 (1974), isgue 3. 